\title{
A Group of Local Production Middle Byzantine Period Pottery from Tripolis
}

Micaceous White Painted Ware

\section{Bahadır Duman}

\section{OpenEdition}

Journals

\section{Electronic version}

URL: http://journals.openedition.org/anatoliaantiqua/307

DOI: 10.4000/anatoliaantiqua.307

\section{Publisher}

IFEA

Printed version

Date of publication: 1 January 2014

Number of pages: 225-234

ISBN: 9782362450136

ISSN: 1018-1946

\section{Electronic reference}

Bahadır Duman, «A Group of Local Production Middle Byzantine Period Pottery from Tripolis », Anatolia Antiqua [Online], XXII | 2014, Online since 30 June 2018, connection on 18 December 2020 URL : http://journals.openedition.org/anatoliaantiqua/307 ; DOI : https://doi.org/10.4000/ anatoliaantiqua.307 


\section{ANATOLIA ANTIQUA ESKI ANADOLU}

\section{XXII}

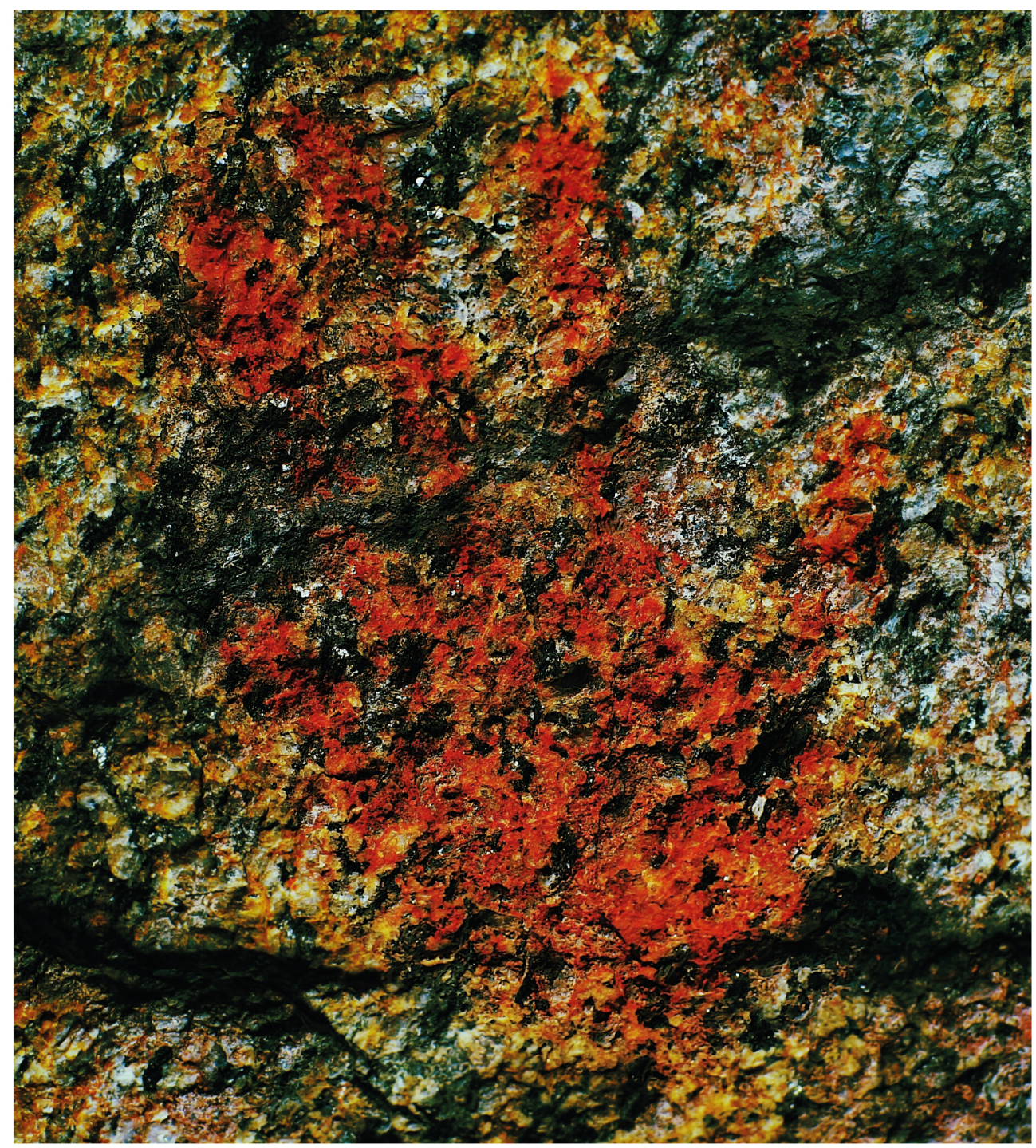

INSTITUT FRANÇAIS D'ETUDES ANATOLIENNES GEORGES-DUMEZIL CNRS USR 3131

DE BOCCARD 


\section{TABLE DES MATIERES}

Emma BAYSAL,

A preliminary typology for beads from the Neolithic and Chalcolithic levels of Barcın Höyük

William ANDERSON, Jessie BIRKETT-REES, Michelle NEGUS CLEARY,

Damjan KRSMANOVIC et Nikoloz TSKVITINIDZE,

Archaeological survey in the South Caucasus (Samtskhe-Javakheti, Georgia):

Approaches, methods and first results

Eda GÜNGÖR ALPER,

Hellenistic and Roman period ceramic finds from the Balatlar Church excavations in

Sinop between 2010-2012

Ergün LAFLI et Gülseren KAN ŞAHİN,

Hellenistic ceramics from Southwestern Paphlagonia

Oğuz TEKIN,

Weights of Lysimachea from the Tekirdağ Museum and various collections

Oğuz TEKIN,

Three weights of Lampsacus

Julie DALAISON et Fabrice DELRIEUX,

La cité de Néapolis-Néoclaudiopolis : histoire et pratiques monétaires

Martine ASSENAT et Antoine PEREZ,

Amida 4. Constance II et Amida

Sencan ALTINOLUK et Nilüfer ATAKAN,

Abrasax: A magical gem in the Istanbul Archaeological Museums

Bahadır DUMAN,

A group of local production Middle Byzantine period pottery from Tripolis:

'Micaceous White Painted Ware'

CHRONIQUES DES TRAVAUX ARCHEOLOGIQUES EN TURQUIE, 2014

Jean-Charles MORETTI,

avec la collaboration de Nicolas BRESCH, Isabel BONORA, Jean-Jacques MALMARY et

Olivier RISS,

Claros, le Temple d'Apollon : travaux réalisés en 2013

Suat ATEŞLIER,

On the excavations of the Zeus Temple of Alabanda 
Olivier HENRY,

avec Ayşe Güliz BİLGIN ALTINÖZ, Jesper BLID, Ömür Dünya ÇAKMAKLI, Andrew DUFTON, Agneta FRECCERO, Linda GOSNER, Ragnar HEDLUND, Pascal LEBOUTEILLER,

Vasilica LUNGU, Felipe ROJAS, Fredrik TOBIN, Baptiste VERGNAUD et

Andrew WATERS,

La mission Labraunda 2013 - Rapport préliminaire

Dominique BEYER, Isabelle CHALIER, Françoise KIRNER,

Françoise LAROCHE-TRAUNECKER et Aksel TIBBET,

Zeyve Höyük - Porsuk. Rapport préliminaire sur la campagne 2013

Çiğdem MANER,

Preliminary report on the first season of the Konya-Ereğli (KEYAR) survey 2013 


\section{A GROUP OF LOCAL PRODUCTION MIDDLE BYZANTINE PERIOD POTTERY FROM TRIPOLIS \\ 'Micaceous White Painted Ware'}

\section{INTRODUCTION}

Tripolis is located within the municipal boundaries of Yenicekent in the Buldan District, Province of Denizli in Turkey. In the ancient period, it was significant for being at the convergence of Lydian, Carian and Phrygian territory (Fig. 1). According to the ancient sources the trade route from Pergamon (Bergama) via Germe passed through Thyateria (Akhisar), Sardeis (Salihli), Philadelphia (Alaşehir) before heading towards Tripolis (Yenicekent), Hierapolis (Pamukkale) and Laodicea (Goncalı) (Ramsay 1890: 49). The presence of this major trade route guaranteed Tripolis its significance for centuries. The commercial and social relation Tripolis had established with other ancient cities along the mentioned trade route is becoming increasingly evident with the archaeological material found at the site.

Over the years, various institutions have commissioned teams to carry out surface surveys and archaeological excavations at Tripolis (Atik and Erdem, 2004: 9 et al.; Ceylan 1995: 159 et al.; Erdoğan and Çörtük 2009: 107; Erdoğan 2011: 328). The third term excavations at Tripoli commenced in 2012, following a three-year interval. The excavations are headed by Denizli Provincial Directorate of $\mathrm{Mu}-$ seums and continue under the scientific supervision of the author of this paper (Duman 2013: 179). Although work conducted prior to the third term excavations had revealed information about the town's Hellenistic, Roman and Early Byzantine Periods, nothing had been reported about the Middle Byzantine Period. Along with other settlements in the region, the earthquake of 494 A.D. affected Laodicea, Agathe Kome and Tripolis (Ramsay 1895: 38, footnote 3 and 262). The town's population diminished from the late $6^{\text {th }}$ century A.D. on. Available information suggests that signs of a powerful settlement did not emerge until the $13^{\text {th }}$ century A.D. Leading his army through Tripolis during the Third Crusade, Friedrich Barbarossa found the town ruined and deserted (Eickhoff 1977: 99). This is an indication that the castle built by John III Ioannes Doukas Vatatzes, Emperor of Nicaea, in the first half of the $13^{\text {th }}$ century A.D. on the hill North of Tripolis, was not the improvement of an existing fortification, but rather an entirely new castle. Therefore the town's population started to shrink considerably beginning from the end of $6^{\text {th }}$ century A.D. on. One of the most important aspects of the archaeological finds unearthed in recent years is a group of pottery, which sheds light on the Middle Byzantine Period of the town.

\section{FINDS AND SITES}

61 pieces of pottery have been unearthed at the excavations at Tripolis until now (Fig. 2-3). In literature these are referred to as 'Micaceous White Painted Ware'. Of these pieces three were found in the Arched Structure, one on the Columned Road, five in Early Byzantine Church 4 while the remaining 52 were unearthed in a level about 2 metres above the portico floor surface inside the Late Roman Agora that was completed around the $4^{\text {th }}$ century A.D. (Fig. 4).

The western portico of the Agora is linked to the Columned Road through a door opening from the southern fortification walls. The Agora must have been severely damaged by Sassanid invasions at the beginning of the $7^{\text {th }}$ century A.D. (ca. 610 A.D.) since an extensive area at the portico base level reveals fire traces and remains of burnt wood. Following the Sassanid destruction, the columns supporting the roof over the portico were relocated to the eastern side of the promenade. The gaps between the columns in the original site were simply filled with bricks and broken pieces of travertine allowing the use of the promenade for a little longer

*) Pamukkale Üniversitesi, Fen-Edebiyat Fakültesi, Arkeoloji Bölümü. 


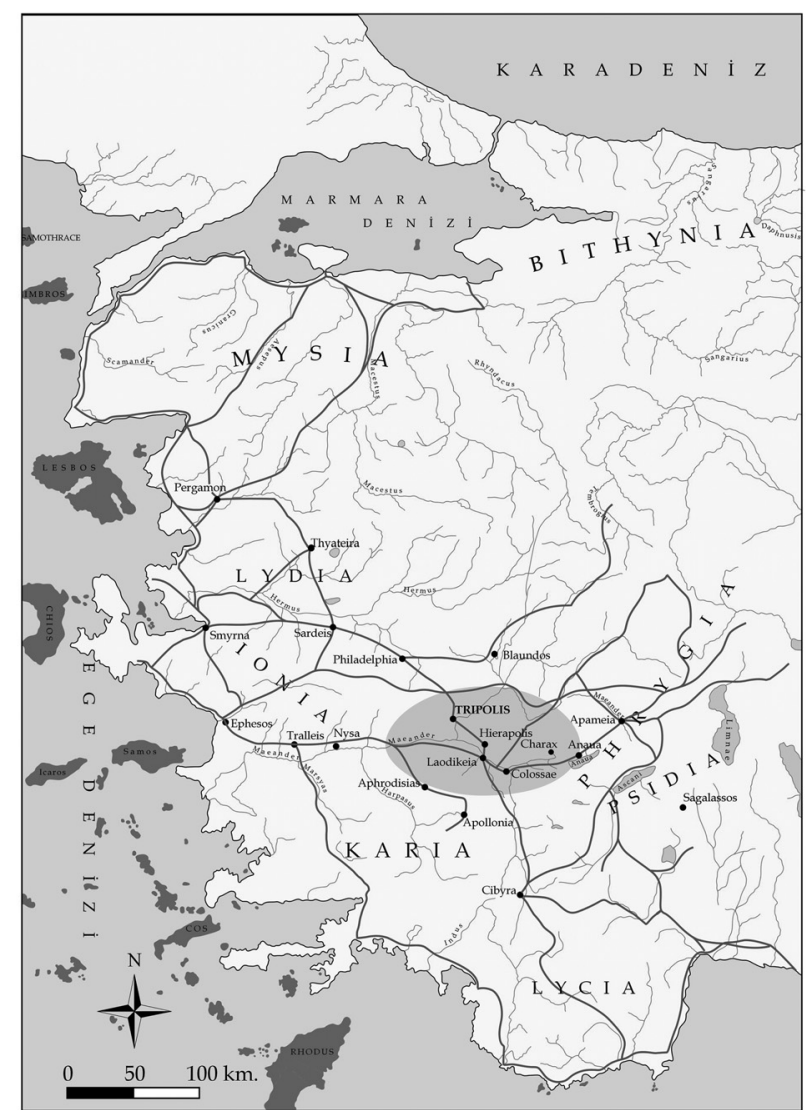

Fig. 1 : Location of Tripolis.

(about until mid- $7^{\text {th }}$ century A.D.). Two coins from the Constans II period, ca. 641-668 A.D., are the latest finds that can provide a dating on this area. Reviewing available information, it emerges that there is no data from the compactly filled area starting from the second half of the $7^{\text {th }}$ century A.D. until the level containing the white painted ware is reached. The only piece of data found together with the ware group, which can provide a reliable date, is the anonymous follis that can be dated to ca. 9761030 A.D.

Another area for the Micaceous White Painted Ware finds in Tripolis is the building named Early Byzantine Church 4, which has been somewhat squeezed into the narrow space between the Columned Road and the Arched Structure to the North. The building in which the mentioned coin was found is a small church. Although the church was originally constructed in the $5^{\text {th }}$ century A.D., finds suggest that it remained in use until the mid $10^{\text {th }}$ century having undergone various repairs.

\section{PASTE, SLIP AND DECORATIONS}

The majority of finds from the upper layers of the portico base and the church consist of rim, neck and body fragments of amphorae and flagons for liquid transportation, however five samples have the form of a jug (Cat. $\mathbf{N}^{\mathbf{0}}: \mathbf{1 , 4 - 7}$ ). The examined pieces present coherence because the clay colour is brick red and its shades. The clearly visible silver mica is the striking common feature in all the pieces. Additives other than mica include quartz, sand and small stones. Many of the samples had been exposed to high temperatures during baking, resulting in a brittle structure and grey-dark grey colour changes can be observed in the clay.

The colour of slip used extensively on the semimat and slightly coarse exterior surfaces is a few shades lighter than the colour of clay. Two pieces feature off-yellow coloured bands painted on dark brown lining that have been filled with zigzag painting in background colour or by means of carving out notches (Cat. $\left.\mathbf{N}^{\mathbf{0}}: \mathbf{1}, \mathbf{2}\right)$. The same decoration is repeated on the exterior of some jars, however the continuous bands created using white paint is not found on all samples. The main background in 59 of the pieces is made of lighter or darker shades of brick-red. Some of the samples feature cream or white-coloured bordering continuous bands on the top and base of the pot body. While in some samples the bands have been left plain, in others, the bands have been decorated with zigzags or notch decorations $\left(\right.$ Cat. $\mathbf{N}^{\mathbf{0}}$ : 1-3, 9, 11, 12). The area between the bordering bands at the top and bottom of the pot have sometimes been decorated with wide waves in white (Cat. $\mathbf{N}^{\mathbf{0}}: \mathbf{1 0}$ ), whilst in other cases this area is filled with incised hatching decorations (Cat. $\mathbf{N}^{\mathbf{0}}$ : 13, 14).

Especially coherent with the shape of closed forms, the band decorations seen on the surface are mostly off yellow in colour (Cat. $\mathbf{N}^{\mathbf{0}}$ : 9). Having said that, white paint was used on a single mouthlip piece from an amphora (Cat. $\mathbf{N}^{\mathbf{0}}$ : 12). Paint marks can be seen on 11 handle pieces. Yellow coloured paint was used to create vertical bands for decoration on these pieces (Cat. $\mathbf{N}^{\mathbf{0}} \mathbf{2}$ 22, 27), some of the finds include examples of white paint use (Cat. No: 23-25).

The handles of the amphora, flagons or jars feature single, double rows or irregular series of holes that have been opened with a sharp, pointy tool (Cat. $\left.N^{0}: \mathbf{8}, 15,17,20-22\right)$. In some examples the force applied from above has created positive embossing on the underneath (Cat. $\mathbf{N}^{\mathbf{0}}: \mathbf{1 7}, \mathbf{2 1}$ ), and in one example a sharp, pointy tool pushed from the top has gone straight through side creating a hole on the other side 

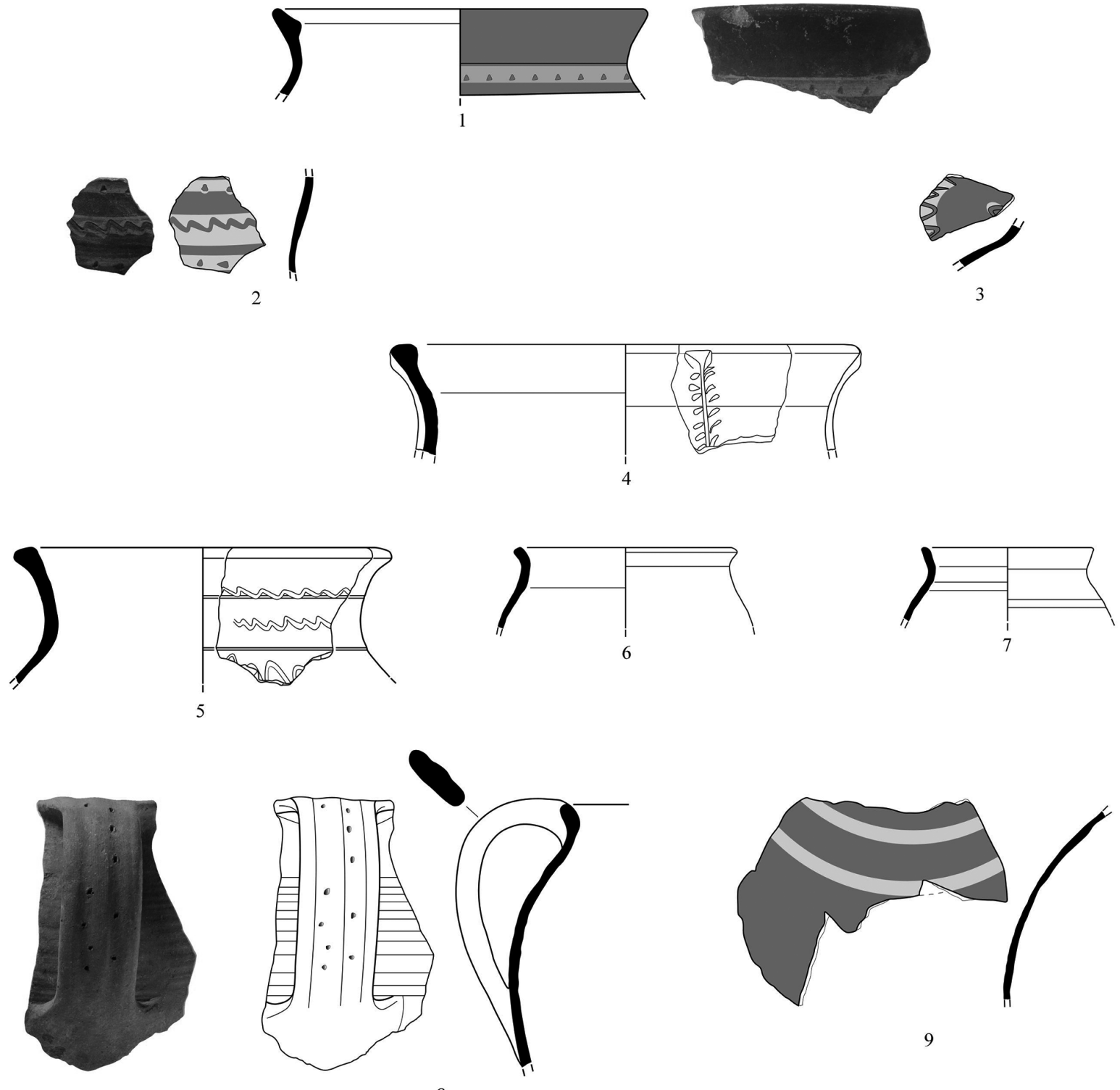

8
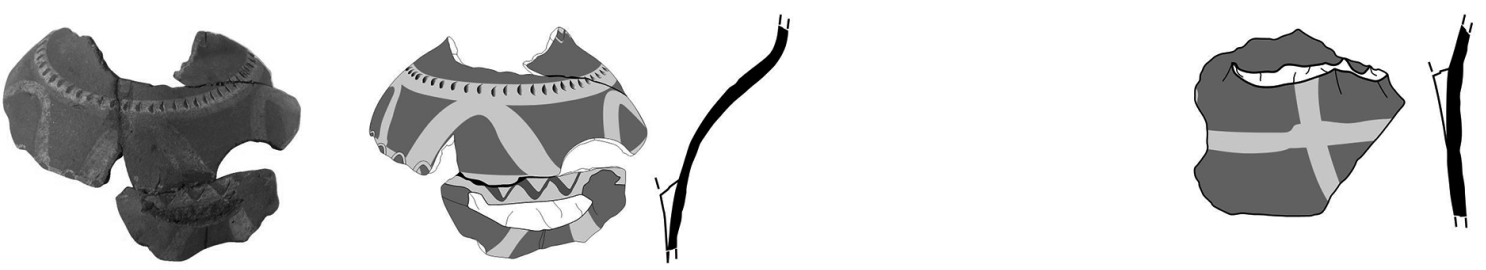

10

11

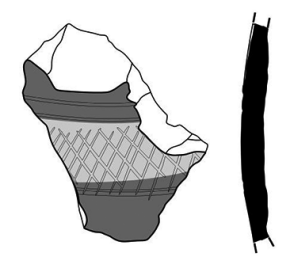

13

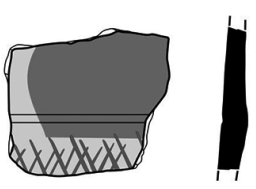

14

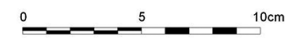

Fig. 2 : Mid-Byzantine ceramics. 


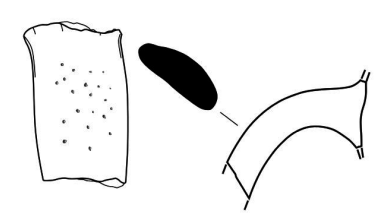

15

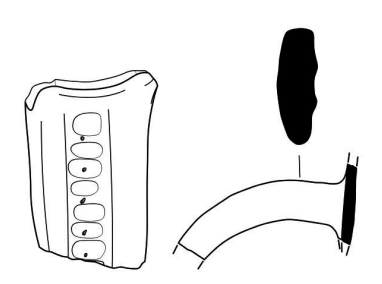

17

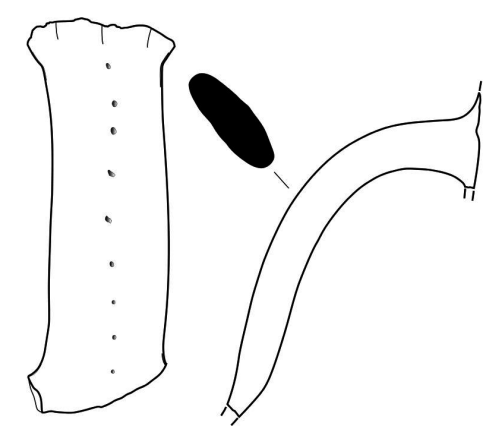

20

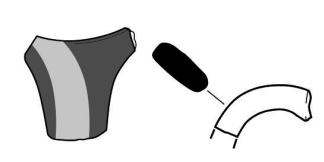

23

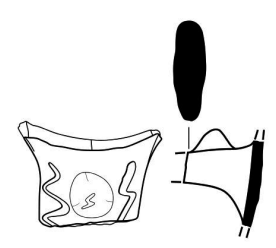

26

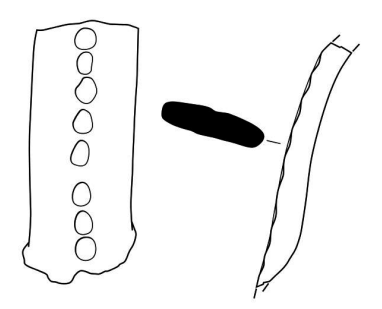

18

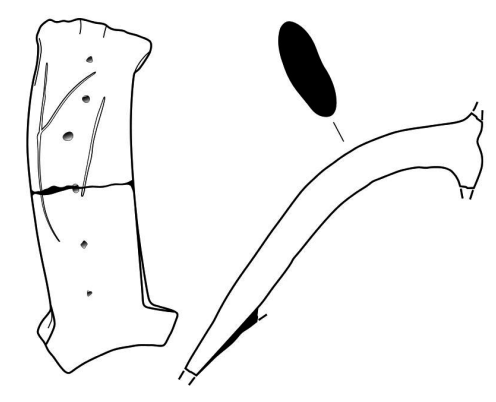

21

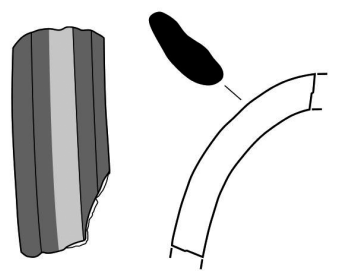

24

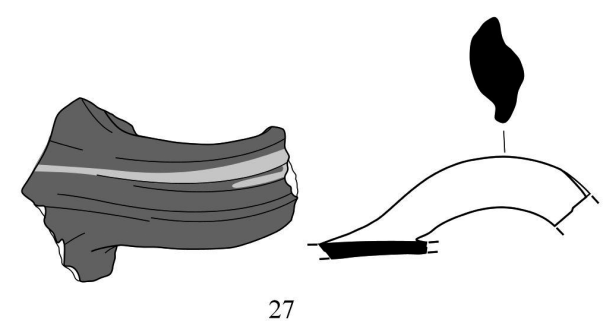

25

22
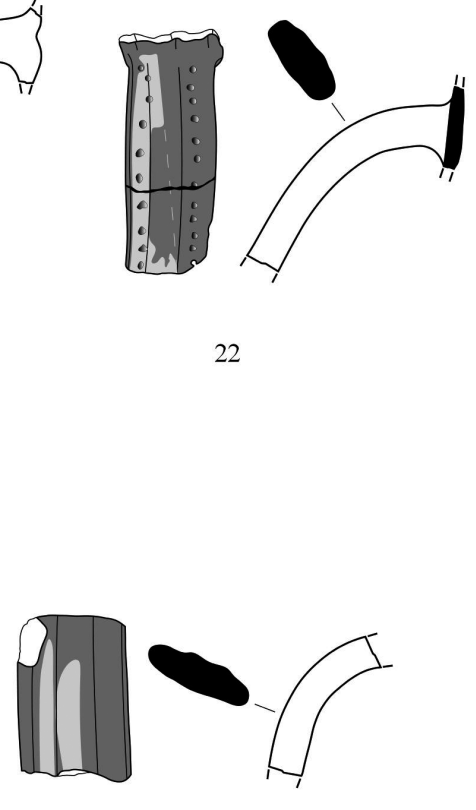
${ }^{\circ}-C^{5}-{ }^{10 \mathrm{~cm}}$

Fig. 3 : Mid-Byzantine ceramics handles. 


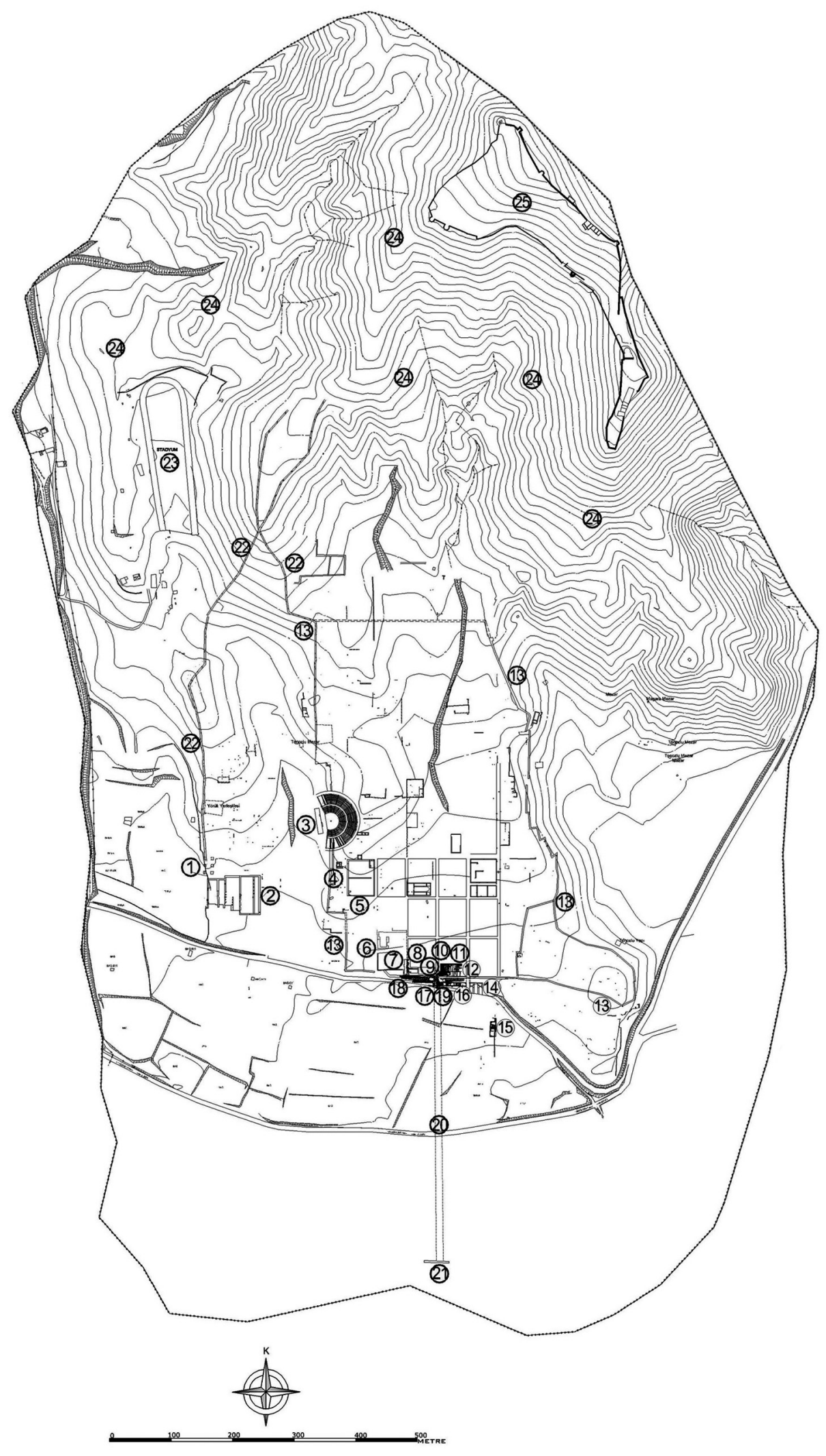

1. Philadelphia Kapısı

2. Büyük Hamam

3. Tiyatro

4. Tiyatro Hamamı Sarnıc

5. Tiyatro Hamamı

6. Meclis Binası (Bouleuterion)

7. Geç Roma Agorası Batı Portiği

8. Geç Roma Agorası

9. Erken Bizans Kilisesi 4

10. Kemerli Yapı Batı Portiği

11. Kemerli Yapı

12. Roma Dükkanları

13. Erken Bizans Surları

14. Erken Bizans Kilisesi 2

15. Mozaikli Villa

16. Sütunlu Cadde, Bizans Mekanları

17. Güney Giriş Kapısı 1

18. Güney Giriș Kapısı 2

19. Orpheus Çeşmesi

20. Hierapolis Caddesi

21. Hierapolis Kapısı

22. Geç Bizans Surları

23. Stadyum

24. Nekropol Alanları

25. Yukarı Kale

Fig. 4 : Tripolis general plan. 
(Cat. No: 15). There are doubts as to whether the holes seen particularly on the handles of the wares from the same group found at Hierapolis are for firing or decorative purposes (Cottica 1998: 82, Fig. 3, nn. 10- 12). From the 48 handle pieces unearthed at Tripolis, 31 had single or double rows and sometimes irregular holes. The other six pieces did not have holes (Cat. $\mathbf{N}^{\mathbf{0}} \mathbf{2}$ 23-27). Some of the unearthed samples feature irregular holes. It is evident that these holes on the handles were opened for purposes of firing rather than decoration (Cat. $\left.\mathbf{N}^{0}: \mathbf{8}, \mathbf{1 5}\right)$. Holes can also be seen on one of the handles (Cat. No: 17) featuring finger print decorations (Cat. $\mathbf{N}^{\mathbf{0}}$ : 17, 18). A single sample that was different from the plain or holed handles belongs to a closed vessel and features incised small wave decorations (Cat. $\mathbf{N}^{\mathbf{0}}: \mathbf{2 6}$ ). A knob can be seen in the middle. A similar knobbed aplication can be seen on a flagon handle unearthed at Hierapolis (Cottica 2007: 263, Fig. 13, 3). Notched decorations have been used on Cat. $\mathbf{N}^{\mathbf{0}}$ : 19 instead of holes. On another handle, it is possible to observe round shaped decorations in the form of deep edges with an embossed centre that has been made with the help of a tool (Cat. No: 16).

\section{CENTRES OF FINDS}

Pottery resembling those unearthed at archaeological excavations carried out at Tripolis has been found particularly in Hierapolis and other settlements along the Çürüksu/Lykos valley, namely at Laodikeia and Çardak/Charax.

Archaeological excavations carried out at Hierapolis have unearthed pottery from the same group inside different structures and buildings (Arthur 1997: 531; Cottica 1998: 81- 83; Caggia 2007: 294, Fig.19; Cottica 2007: 255). Samples found at the Hierapolis excavations have been named 'Micaceous White Painted Ware' (Cottica 1998: 82). Work carried out at the spaces named as 'silo', adjacent to the south side of Frontinus Street has revealed a large piece of a pot featuring two white painted band decorations which has been dated to the $10^{\text {th }}$ century A.D. (Arthur 1997: 534, 539, Fig. 6: 10- 11). There are similarities in form and decoration between the flaring rim jars of Tripolis and those found at Hierapolis. Body and lip pieces from large-scale white painted vessels have been unearthed in close proximity to the building named 'Large Structure' adjacent to the south side of Frontinus Street in Hierapolis. Pottery finds have been discovered, in the proximity of the mentioned structure, at the base level of dwellings that were destroyed during the earthquake that took place in $9-10^{\text {th }}$ century A.D. (Caggia 2007:
294, Fig. 19). Another area for finds at Hierapolis is the structure known as the 'Casa dei Capitelli Ionici'. Pottery of similar characteristics was discovered in this structure that has been dated to the $8-10^{\text {th }}$ centuries A.D. (Cottica 1998: 82). 'Insula 104' is the source of finds belonging to the pottery group decorated with white bands, lines or incised lines at the excavations at Hierapolis. The pottery unearthed at this location in recent years has been morphologically and chronologically evaluated. While the majority of finds discovered at 'Insula 104' consists of white paint decorated pottery, plain slip and undecorated versions of the aforementioned painted and notch decorated examples were found in the same layers (Cottica 2007: 261, Fig. 4-7, Fig. 11-13; Ruggiu and Cottica 2007: 175-181, fig. 11-13). Although the approach to decoration in the pottery categorised as 'Micacaeous White Painted Ware' is similar the form repertoire consists of pieces from jugs, double handle flagons and amphorae. Cottica argues that the group in 'Insula 104', still in use in the $10^{\text {th }}$ century A.D., could have been used since the Dark Ages. Cottica also suggests that this form disappeared in the first half of the $11^{\text {th }}$ century A.D. while the white paint decorated vessels were replaced by ribbon decorations created with finger printing (Cottica 2007: 266).

Pottery with white painted body and handles was also unearthed at another Çürüksu/Lykos Valley city: Laodicea. After the settlements were severely damaged by earthquakes, Laodicea was abandoned to a great extent as of the mid- $7^{\text {th }}$ century A.D. (Şimşek 2013: 58). Archaeological excavations taking place in the city since 2003 have found only a very small amount of finds dating later than the mid $7^{\text {th }}$ century A.D. Prior to excavation work, an Italian team performed a survey of Laodicea between 1994 and 2001 and discovered pottery from the white band group inside the rectangular shaped late period settlement areas consisting of a few adjacent rooms in the middle of the stadium (Gelichi and Negrelli 2004: 251, 253, Tav. XIII.4, fig. 32.8-10, 33.12-13, 34.19-21). The dates suggested for the micaceous white painted group of pottery discovered during the surveys of Laodicea corresponds with samples discovered at Hierapolis (Gelichi and Negrelli 2004: 253-254).

\section{EVALUATION AND DATING}

The intensely micaceous white painted ceramics unearthed at Tripolis makes the settlement the second most significant centre of finds amongst the Lykos/Çürüksu cities, after Hierapolis. This pottery 


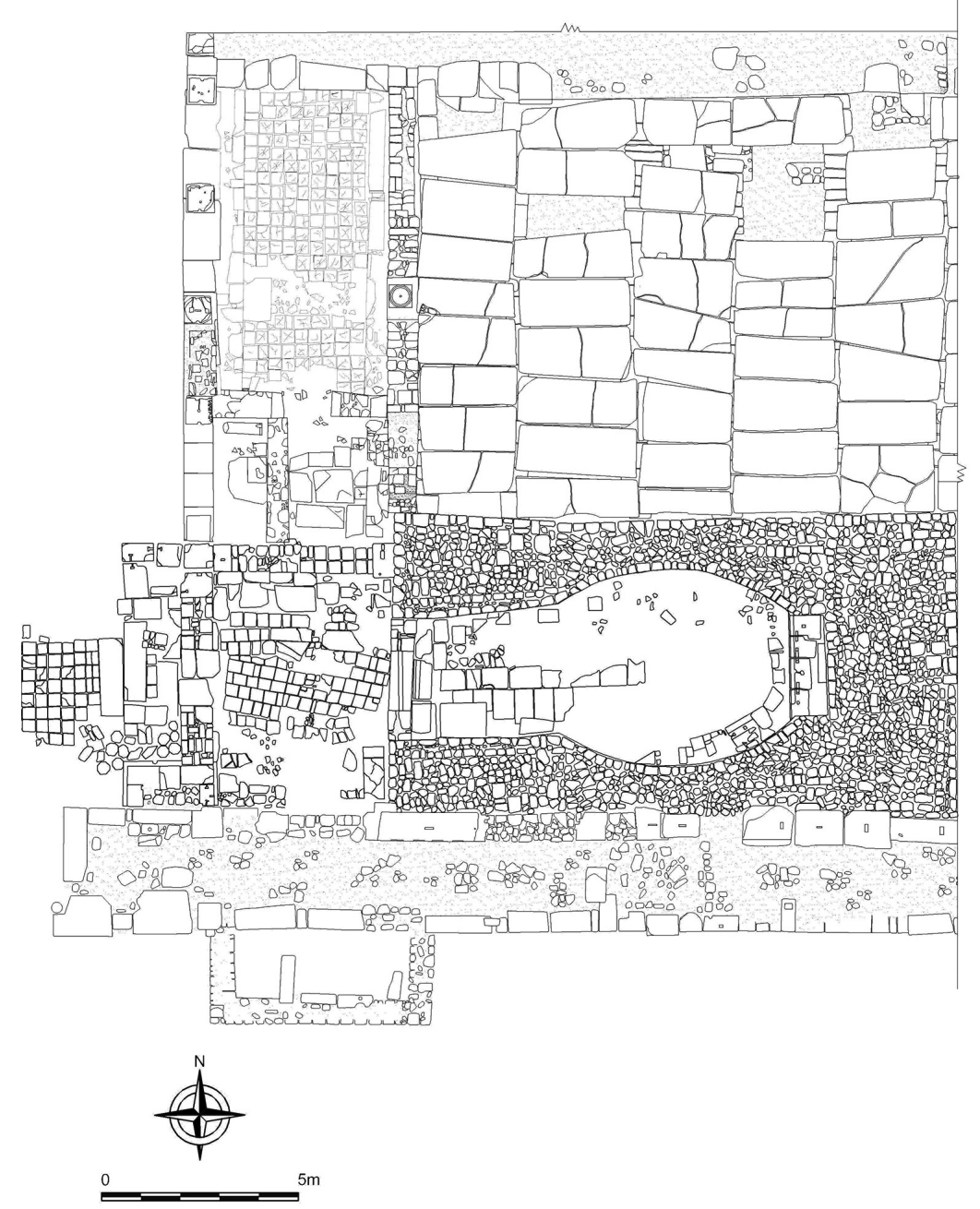

Fig. 5 : Early Byzantine Church 4 plan.

group was found in several structures in Hierapolis, particularly the 'Casa dei Capitelli Ionici'. Considering the number of excavation sites, their existence in Tripolis is more limited. Taking into account the Hierapolis, Laodicea and Charax/Çardak examples in terms of form and decoration repertoire and the fact that finds are, at least for now, only limited to the area, it is possible to suggest the existence of local production in the Lykos Valley.

The inhabitants of Tripolis suffered significantly from the Sassanid Invasions and earthquakes taking place in the first quarter of the $7^{\text {th }}$ century A.D. Looking at the data acquired from the archaeological material unearthed here, it is possible to say that life in the city almost completely faded as of the mid- $7^{\text {th }}$ century A.D. Coins provide the most important data regarding the mentioned period in Tripolis. The dates of the coins discovered at the excavations taking place until today start from the $1^{\text {st }}$ century A.D. and, with certain hiatus, go on until the Emperor Phocas period, ca. 602-610 A.D. After 610 A.D., there is approximately a 30 -year gap, indicated by only two Constans II coins that were discovered. This suggests that life in the city continued a few more decades after the Sassanid raids. The dates of uninterrupted habitation and gaps that can be followed with coin finds are almost identical to dates acquired from other find groups. After the Constans II coins dated to $c a$. 641-668 A.D., the approximately $2 \mathrm{~m}$ thick earth fill is completely bare of archaeological material. However the anonymous follis dated to ca. 976-1030 A.D. that was discovered alongside the pottery group that is the subject of this paper is chronologically quite significant. It was issued between 945-959 A.D., the years which Emperor Constantine VII and his son Romanus II jointly ruled the empire. The structure in which the mentioned coin was found is a small chapel known as Early Byzantine Church 4 (Fig. 5). Although the small church was originally constructed in the $5^{\text {th }}$ century A.D., findings suggest that it remained in use until the mid $10^{\text {th }}$ century having undergone various 


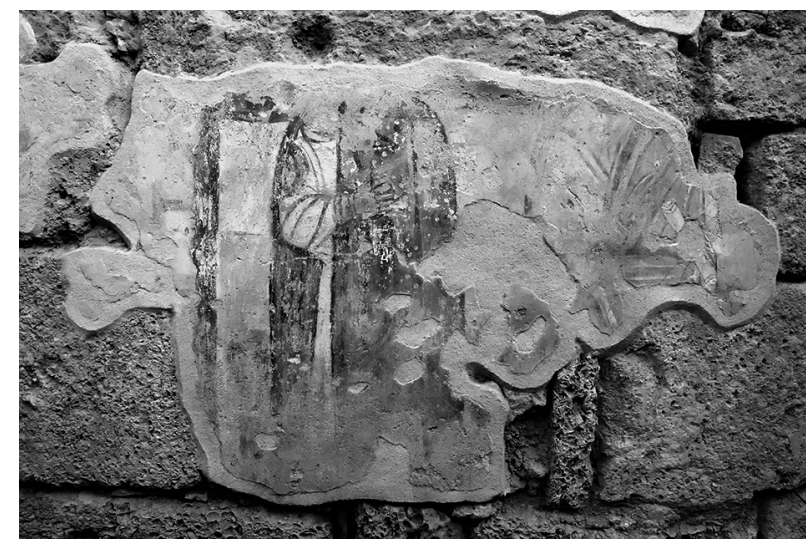

Fig. 6 : A detail from fresco in the Church.

repairs. The frontal view depictions of two Saints above the fresco on the north body wall and the coin found at the base level must be related to the church's last date of use (Fig. 6).

Considering the comparison with other find centres, particularly Hierapolis, and the archaeological layers and finds in which the discovered pottery was located it is possible to suggest the third quarter of the $10^{\text {th }}$ century A.D. and the first quarter of the $11^{\text {th }}$ century A.D. as the date for the micaceous white painted wares. The mentioned ware finds are significant in that they prove the existence of a Middle Byzantine Period settlement in Tripolis during the indicated dates. Ware from the mentioned group became known as 'Micaceous White Painted Ware' with the finds discovered at Hierapolis a few decades ago. In addition to Hierapolis and Laodicea, examples of such wares were discovered in neighbouring Tripolis. The geography in which these wares were used was expanded in scope of the study and consequently it was possible to reach results that chronologically support the finds at Hierapolis.

B.D.

\section{CATAlogue}

All measurements in the catalogue are in centimetres. Below is a legend for the abbreviations that have been used throughout the text and catalogue: Cat. No. Catalogue number, H. Height, G. Width, R.D. Rim Diameter, W.T. Wall Thickness, HT. Handle Thickness, HW. Handle Width. The revised (2010) version of Munsell Soil-Colour Chart 2009 was used as the colour chart.

Cat. $N^{0}: 1$

Y: 5 W.T: 0.4 R.D: 21.2

Jar rim and neck fragment. Rim pulled upwards creating a profile on the inner wall. Slight curve on the transition from neck to body. Triangle decoration on a horizontal band on the body transition. Hard and dense paste, mica and stone inclusions, 2.5 YR 4/6. Semimatte, slightly rough surface, clay colour on the outside, 10 YR 7/4 slip colour inside.

Cat. $\mathbf{N}^{\mathbf{0}}: 2$

H: 5.7 W: 5.2 W.T: 0.4

Jar body fragment. Three separate lines of horizontal painted bands, triangle decorations on the top and bottom, wave decorations in the middle band. Hard paste, mica and stone inclusions, 2.5YR 4/6. Slip semi-matte, slightly rough on the outside, matte-rough surface on the inside, 2.5YR $3 / 1$

Cat. $N^{0}: 3$

W: 3.5 W.T: 0.4

Flagon neck fragment. Slip and wave band decorations on the neck curve and body. Micaceous and stone inclusions, 2.5YR 4/8. Semi-matte, slightly rough slip, 2.5YR $4 / 6$ on the outside and inside, 2.5 Y 8/2 paint on the outside.
Cat. No: $4 \quad$ H: 6.4 W.T: 0.7 R.D: 25.2

Jar rim and neck fragment. Rim pulled upwards creating a profile on the inner wall, flattened on the top. Embossed decoration with notched stamp on the outside of the rim. Hard and dense paste, mica and small stone inclusions, 2,5 YR 5/6. Semi-matte slightly rough slip, lime and dense mica on the outer surface 2.5 YR 5/6, inner surface 5 YR 5/2.

Cat. $N^{0}: 5$

H: 7.9 W.T: 0.4 R.D: 22

Jar rim and neck fragment. Two rows of wavy decorations on the neck an done on the body transition. Hard paste, partially porous, mica and small stone inclusions, 2.5 YR 4/8. Semi-matte slightly rough surfaced slip inner and outer surface colour 2.5 YR 4/6

Cat. $\mathbf{N}^{\mathbf{0}}: 6$

H: 4.7 W.T: 0.3 R.D: 12.2

Jar rim fragment. Medium-hard and dense paste, mica and small stone inclusions, well fired 5YR 4/4. Semi-matte slightly rough surfaced slip 2.5 YR 4/4 both on the inner and outer surface.

Cat. $\mathbf{N}^{0}: 7$

H: 4.3 W.T: 0.3 R.D: 10

Jar rim fragment. Hard and dense paste, mica and small stone inclusions, well fired 5YR 5/4. Semi-matte slightly rough surface, burn marks on the rim. Semimatte slightly rough slip 10 YR $6 / 3$ both on the inner and outer surface.

Cat. No: 8 H: 15.2 W.T: 0.4-0.5 HT: 1.4 HW: 4.2

Casserole rim and body fragment. Irregular dot decoration on two sides of the handle. Hard paste, partially porous, mica and small stone inclusions, 5 YR 4/6. Semi 
matte slightly rough surfaced slip 2.5 YR 5/4 both on the inner and outer surface.

\section{Cat. $N^{\mathbf{0}}: 9$}

H:11 W.T: 0.4 W: 16

Jar body fragment, two rows of band decorations on the body. Medium hard dense paste, mica and small stone inclusions. Medium fired 5YR 5/6. Semi-matte slightly rough surfaced slip 5YR $5 / 4$ both on the inner and outer surface.

Cat. $\mathbf{N}^{\mathbf{0}}: 10$

W.T: 0.5

Flagon body fragment. Notch decoration bordered with paint on the body, paint and incised wavy decorations on the body. Hard and dense paste, mica and small stone inclusions. 2.5 YR 5/6. Semi-matte slightly rough surface in paste colour both in the inner and outer surface. Paint $5 Y 8 / 1$.

Cat. $\mathbf{N}^{\mathbf{0}}: 11$

W: 8.8 W.T: 0.5

Flagon body fragment, broken from handle transition point. Horizontal and vertical single row paint band decoration on the lower part. Hard dense paste, mica and small stone inclusions 2.5 YR 4/8. Semi-matte slightly rough slip 2.5 YR 5/6 both on the inner and outer surface, paint $2.5 \mathrm{Y} 8 / 2$.

\section{Cat. $\mathbf{N}^{\mathbf{0}}: 12$}

H: 4.8 W.T: 0.6 R.D: 11.6

Amphora rim fragment. Two broad horizontal bands. Hard and dense paste, mica and small stone inclusions. 2.5 YR 5/8. Semi-matte slightly rough surface. Inner surface paste colour, outer surface 2.5 YR 5/6, paint 2.5 Y $8 / 2$.

Cat. $\mathbf{N}^{0}: 13$

H: 10.2 W: 8.7 W.T: 0.8

Closed vessel body fragment. Incised hatching bordered with grooves above and below. Upper part coloured with yellow paint. Hard and dense paste, mica and small stone inclusions, 2.5 YR 4/8. Semi-matte slightly rough surface 2.5 YR 5/4 both on the inner and outer surface. Paint on the outer decoration 10 YR $7 / 4$.

\section{Cat. $\mathbf{N}^{\mathbf{0}}: 14$}

H: 6.3 W: 7.3 W.T: $0.7-0.8$

Closed vessel body fragment. Slight horizontal painted band decoration from top to bottom. Rightward facing notch decorations on lines, Hard paste, partially porous, mica and stone inclusions, moderately fired 2.5 YR 4/8. Semi-matte slightly rough surfaced slip 10 YR 5/6 both on the inner and outer surface, paint 2.5 Y $8 / 2$ colour.

Cat. $\mathbf{N}^{\mathbf{0}}: 15$

HT: 1.5 HW: 2.9

Casserole handle fragment. Irregular dot decoration on the handle, hole traces on the bottom part. Hard paste, partially porous, mica and small stone inclusions. $2.5 \mathrm{YR}$ 4/8. Semi-matte slightly rough surfaces slip 2.5 YR 5/6 on the inner and outer surface.

Cat. $\mathbf{N}^{0}: 16$

HT: 1.5 HW: 2.6

Flagon handle fragment. Circular decorations with deep stamps on the sides on the handle. Hard and dense paste, mica and small stone inclusions. 2.5 YR 4/6. Matte-rough surfaced slip 2.5 YR 5/6 on the inner and outer surface.

Cat. $\mathbf{N}^{\mathbf{0}}: 17$

HT: 1.6 HW:4.8

Flagon handle fragment, dotted decoration in a finger stamp on the handle. Hard and dense paste, mica inclusion, 2.5 YR 5/6. Semi-matte slightly rough surface. Inner surface paste colour, outer surface 5 YR 6/4.

\section{Cat. $\mathbf{N}^{\mathbf{0}}: 18$}

HT: 1.2 HW: 4.5

Jar handle fragment, broad finger impression on the handle. Hard and dense paste, mica and small stone inclusions, moderately fired 5YR 5/6. Semi-matte slightly rough surfaced slip 5YR 5/4 both on the inner and outer surface.

\section{Cat. $\mathbf{N}^{\mathbf{0}}: 19$}

HT: 1.7 HW: 4.1

Jar handle fragment. Single row vertical notch decoration on the handle. Hard paste, partially porous, mica and small stone inclusion, 2.5 YR 4/6. Semi-matte slightly rough surfaced 2.5 YR 4/6.

Cat. $\mathbf{N}^{\mathbf{0}}: 20$

HT: 1.7 HW: 5

Amphora handle fragment. Single vertical row of dots on handle. Hard and dense paste, mica and small stone inclusions 2.5 YR 4/6. Semi-matte slightly rough surfaced 2.5 YR 5/6.

Cat. $\mathbf{N}^{\mathbf{0}}: 21$

HT: 1.5 HW: 4.5

Amphora handle fragment decorated with simple lines and single row vertical dot decoration. Hard and dense paste, mica and small stone inclusions. Semi-matte slightly surfaced 2.5 YR 5/6.

Cat. $\mathbf{N}^{\mathbf{0}}: 22$

W.T: 0.4 HT: 1.6 HW: 3.8

Amphora handle fragment. Two rows of vertical dot and paint decoration. Hard and dense paste, mica and small stone decoration, 2.5 YR 4/8. Semi-matte slightly rough surfaced slip 2.5 YR $4 / 6$ on the outside and paint 2.5 Y $8 / 2$.

Cat. $\mathbf{N}^{\mathbf{0}}: 23$

HT: 1.1 HW: 2.6

Flagon rim and handle fragment. Single strip paint decoration on the rim and handle. Hard and dense paste, mica and small stone inclusions. Moderately fired 2.5 YR 5/6. Semi-matte slightly rough surface in paste colour both inside and outside. Paint on handle 2.5 Y 8/2.

Cat. $\mathbf{N}^{0}: 24$

HT: 1.5 HW: 4

Amphora handle fragment. Vertical paint band decoration on the handle. Hard paste, partially porous, mica and small stone inclusions. 2.5 YR 4/8. Semi-matte slightly rough surface 2.5 YR $4 / 6$ both on the inner and outer surface, paint 2.5 YR 8/2.

Cat. $\mathbf{N}^{\mathbf{0}}: 25$

HT: 4.6 HW: 1.5

Amphora handle fragment. Vertical double paint strip decoration on handle. Hard and dense paste, mica and 
small stone inclusions, 2.5 YR 5/6. Semi-matte slightly rough slip 5 YR $4 / 4$ both on the inner and outer surface. Paint 5 Y 8/2.

Cat. $\mathbf{N}^{0}: 26$

W.T: 0.4 HT: 1.4 HW: 4.2

Jar handle fragment. Knob decoration on handle, incised wavy decoration on the sides and above the knob decoration. Hard and dense paste, mica and small stone inclusions, 5YR 5/6. Semi-matte slightly rough surfaced slip 5YR 5/4 both on the inner and outer surface.

Cat. $\mathbf{N}^{\mathbf{0}}: 27$

HT: 2.2 HW: 4.5

Amphora handle fragment. Paint decoration on the handle. Hard and dense paste, mica and small stone inclusions 2.5 YR 4/6. Semi-matte slightly rough surfaced slip 2.5 YR 5/4 both on the inner and outer surface. Paint 7.5 YR $6 / 6$.

\section{REFERENCES}

Arthur, P., 1997: "Un gruppo di ceramiche alto Medievale da Hierapolis (Pamukkale, Denizli), Turchia Occidentale", Archeologia Medievale XXIV: 531-540.

Atik, N. and Erdem, Z.K., 2004: "Buldan (Denizli) Arkeolojik Kültür Varlıkları Envanteri 2001-2003 Yılı Saptamalarının Değerlendirilmesi”, TÜBA Kültür Envanteri Dergisi 2: 9-39.

Caggia, M.P., 2007: "Il Grande Edificio. Dalle terme romane alle trasformazioni di eta otomana (Regio II, Insulae 3,5)", in D'Andria, F. and Caggia, M.P. (eds.), Hierapolis Di Frigia I, Le Attività delle Campagne di Scavo e Restauro 2000-2003, İstanbul: 279-309.

Ceylan, A., 1995: "Tripolis Sütunlu Caddesinde Yapılan Kazı ve Temizlik Çalışmaları", V. Müze Kurtarma Kazllart Semineri: 159-170.

Cottica, D., 1998: "Ceramiche bizantine dipinte ed unguentari tardo antichi dalla 'Casa dei Capitelli Ionici' a Hierapolis", $R A$ XXII: 81-90.

- 2007: "Micaceous White Painted Ware from insula 104 at Hierapolis/Pamukkale, Turkey", in BöhlendorfArslan, B., Uysal, A.O. and Witte-Orr, J. (eds.), Çanak Late Antique and Medieval Pottery and Tiles in Mediterranean Archaeological Contents [BYZAS 7]: 255-272.
Duman, B., 2013: "Son Arkeolojik Araştırmalar ve Yeni Bulgular Işı̆̆ında Tripolis ad Maeandrum", Cedrus I: $179-200$.

Eickhoff, E., 1977: Friedrich Barbarossa im Orient: Kreuzzugund Tod Friedrichs I [Istanbuler Mitteilungen, Beiheft 17], Tübingen.

Erdoğan, A. and Çörtük, U., 2009: "Tripolis Kazıs1 2007 Yılı Çalışmaları”, KST 30-4: 107-138.

Erdoğan, A., 2011: "Tripolis 2008- 2009 Y1lı Kazıları", KST 32-3: 328- 347.

Gelichi, S. and Negrelli, C., 2004: "Le Ceramiche", in Bejor, G., Gelichi, S. and Traversari, G. (eds.), Laodicea Di Frigia II, La Ricognizione 2000, Padova: 239- 258.

Ramsay, W.M., 1890: The Historical Geography of Asia Minor, London.

- 1895: The Cities and Bishoprics of Phrygia: Being An Essay of the Local History of Phrygia from the Earliest Times to the Turkish Conquest, Vol. 1.1, The Lycos Valley and South-Western Phrygia, Oxford.

Ruggiu, A.Z., and Cottica, D., 2007: "Hierapolis di Frigia fra Tarda Antichità ed XI secolo: L'apporto dello Studio degli Spazi domestici nell' Insula 104', $R d A$ 31: 139- 189.

Şimşek, C., 2013: Laodikeia, İstanbul. 


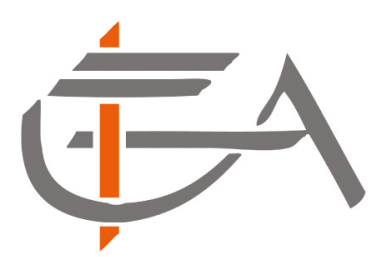

Institut Français

d'Etudes Anatoliennes

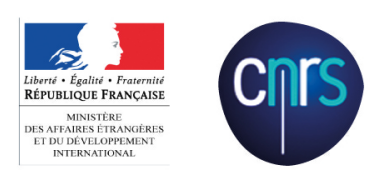

Peinture rupestre préhistorique, Sağlık Köy, près d'Alabanda, Turquie (cliché Suat Ateşlier). 